\title{
Tracheospasmolytic and anti-inflammatory activity of indigenous Curcuma species as traditional antiasthmatic medicines
}

\author{
SWANDARI PARAMITA ${ }^{1,2, \boldsymbol{v}}$, EMIL BACHTIAR MOERAD ${ }^{3}$, SJARIF ISMAIL ${ }^{2,4}$, EVA MARLIANA $^{5}$ \\ ${ }^{1}$ Department of Community Medicine, Faculty of Medicine, Universitas Mulawarman. Jl. Kerayan, Kampus Gunung Kelua, Samarinda 75119, East \\ Kalimantan, Indonesia. Tel./fax.: +62-541-748581, `email: swandariparamita@gmail.com \\ ${ }^{2}$ Center for Medicine and Public Health Research, Institute for Research and Community Services, Universitas Mulawarman. Jl. Kerayan No. 1 Gedung \\ A 20, Kampus Gunung Kelua, Samarinda 75119, East Kalimantan, Indonesia \\ ${ }^{3}$ Department of Internal Medicine, Faculty of Medicine, Universitas Mulawarman. Jl. Kerayan, Kampus Gunung Kelua, Samarinda 75119, East \\ Kalimantan, Indonesia \\ ${ }^{4}$ Department of Pharmacology, Faculty of Medicine, Universitas Mulawarman. Jl. Kerayan, Kampus Gunung Kelua, Samarinda 75119, East Kalimantan, \\ Indonesia \\ ${ }^{5}$ Department of Chemistry, Faculty of Mathematics and Natural Sciences, Universitas Mulawarman. Jl. Barong Tongkok No. 4, Kampus Gunung Kelua, \\ Samarinda 75123, East Kalimantan, Indonesia
}

Manuscript received: 2 April 2018. Revision accepted: 19 May 2018.

\begin{abstract}
Paramita S, Moerad EB, Ismail S, Marliana E. 2018. Tracheospasmolytic and anti-inflammatory activity of indigenous Curcuma species as traditional antiasthmatic medicines. Nusantara Bioscience 10: 105-110. Asthma is still a major health problem in the world. Antiasthma drugs raise the problem of side effects and medical expenses. Thus, it is necessary to develop medicinal plants based antiasthma drugs with fewer side effects and more affordable costs. The potential antiasthma medicinal plant came from the genus of Curcuma (Zingiberaceae family). Turmeric (Curcuma longa L.) is the most prominent species in this genus and has been extensively studied for the treatment of asthma. However, there are other Curcuma indigenous species that are also traditionally used for asthma, namely Curcuma aeruginosa Roxb. and Curcuma mangga Val. Zijp. Both indigenous species have not been studied pharmacological activity as an antiasthma. This research was conducted to know the tracheospasmolytic activity of ethanol extract of $C$. aeruginosa and C. mangga on the separate organ of guinea pig trachea to determine the antiasthma effect. The research was also conducted to know anti-inflammatory activity with membrane stabilization test and inhibition of lipoxygenase. Results showed that $C$. aeruginosa and $C$. mangga had lower tracheospasmolytic activity when they were compared with aminophylline as a positive control. However, the $\mathrm{EC}_{50}$ value of $C$. aeruginosa $(0.020 \pm 0.004)$ and $C$. mangga $(0.039 \pm 0.005)$ were not significantly different with aminophylline $(0.016 \pm$ $0.005)$ as positive controls. The result of membrane stabilization test showed that the $\mathrm{EC}_{50}$ value of C. aeruginosa (47.76 \pm 1.57$)$ and $C$. mangga $(67.50 \pm 0.97)$ were high when they were compared with indomethacin $(26.39 \pm 2.91)$ as the positive control. Results of lipoxygenase inhibition test showed that the $\mathrm{EC}_{50}$ value of $C$. aeruginosa $(-111.11 \pm 2.30)$ and $C$. mangga $(-101.98 \pm 1.32)$ were high than that of indomethacin $(-282.84 \pm 7.41)$ as the positive control. These results show the potential use of $C$. aeruginosa and $C$. mangga as antiasthma via tracheospasmolytic activity in separate organs of guinea pig. They also had anti-inflammatory effect based on membrane stabilization and inhibition of lipoxygenase test.
\end{abstract}

Keywords: Anti-asthma, anti-inflammatory, Curcuma aeruginosa, Curcuma mangga, tracheospasmolytic

\section{INTRODUCTION}

Asthma is a chronic inflammatory airway disease characterized by the occurrence of respiratory airway hyper response and reversible narrow airway (Kasper et al. 2015). Asthma is one of the major non-communicable diseases in the world. About 235 million people worldwide suffer from asthma, especially in children. The main risk factor for the occurrence of asthma is a combination of genetic susceptibility to environmental exposures such as air pollution (WHO 2018). Asthma medications are given to manage asthma sufferers (Papadakis and McPhee 2013). Herbal preparations are one of the most popular complementary treatment used by asthmatic patients. Almost $40 \%$ of people with asthma use herbal medicines. Many important asthma drugs such as B2-agonists, anticholinergics, methylxanthines, and cromones have herbal origins (Karaman et al. 2012). Research also shows that some medicinal plants have the effect of reducing smooth muscle stiffness. The mechanism of those medicinal plants is similar to the mechanism of asthma drugs, especially the anticholinergic drug (Amit and Vandana 2013). Research also shows that some medicinal plants have the anti-inflammatory effect, which is the same with the mechanism of corticosteroid drug in asthma drugs (Paramita et al. 2017).

The genus Curcuma (Family Zingiberaceae) comprising more than 100 species have been recognized widely as food and traditional medicines. C. longa (turmeric) is the most studied species of all Curcuma species (Akarchariya et al. 2017). Indonesia is home to many species of Curcuma and several species of these have been commonly used as traditional medicines. The various species of Curcuma often used are C. longa (turmeric), $C$. xanthorrhiza, C. heyneana, C. aeruginosa, C. mangga, and C. zedoaria. Turmeric appears to be the species, which is most frequently used as raw materials for traditional medicine in Indonesia, followed by C. xanthorrhiza. The 
other species, including $C$. aeruginosa and C. mangga, are considered as indigenous Curcuma species, which are not intensively studied, yet (Rahayu et al. 2011). The rhizomes of other Curcuma species are also pharmacologically important but several of these species are not exploited commercially (Shakeri et al. 2017).

Important medicinal plants from genus Curcuma having anti-asthmatic potential is $C$. longa. Other rhizomes of Curcuma species are traditionally used in the treatment of asthma, i.e., C. aeruginosa (Rajamma et al. 2012), C. mangga (Dewangan et al. 2014), C. caesia (Pathan et al. 2016a; Pakkirisamy et al. 2017), and C. zedoaria (Pathan et al. 2015). The examination of antiasthma effects of two indigenous Curcuma species, i.e., C. aeruginosa, and $C$. Mangga is not studied, yet. Therefore, the objective of this study was to know the tracheospasmolytic and antiinflammatory activity of $C$. aeruginosa and $C$. mangga applied on isolated trachea of guinea pig.

\section{MATERIALS AND METHODS}

\section{Sampling and sample identification}

The sampling of medicinal plants was conducted at the Kutai Kartanegara District, East Kalimantan. Plants were then identified in the Department of Biology, Faculty of Mathematics and Natural Sciences, Mulawarman University to certify the plant legality. This study has obtained the ethical clearance of the Medical and Health Research Ethics Commission, Faculty of Medicine, Mulawarman University. This study was conducted in the Pharmacology Laboratory of the Faculty of Medicine, Mulawarman University.

\section{Plant extractions}

The extraction of medicinal plant followed the guidelines from the Indonesian Herbal Pharmacopoeia (MoH RI 2008). The rhizomes of $C$. aeruginosa and $C$. mangga were dried and then crushed into simplicia. The simplicia were then macerated using absolute ethanol solvent in a ratio of 1 part of simplicia to 10 parts of solvent. The mixture was soaked for 6 hours followed by stirring occasionally with an orbital shaker at room temperature in each interval hours, which were then stood for 18 hours. The mixture was separated using filter paper, followed by the evaporation using a rotary evaporator at $50^{\circ} \mathrm{C}$. The obtained viscous extract was dried to obtain a dry extract. The dried extracts were then stored in a refrigerator of $-20^{\circ} \mathrm{C}$ for further study.

\section{Tracheospasmolytic activity}

Tracheospasmolytic activity of medicinal plant extracts was tested in separated organs of tracheal guinea pigs via histamine injection. Guinea pigs were sacrificed and the trachea was quickly dissected by adhering fat and connective tissue. Trachea was placed in the petri dish containing Krebs Physiological Salt Solution (PSS). The rings were suspended in L-shaped wire loops in $10 \mathrm{ml}$ organ baths containing the Krebs PSS aerated with carbogen by maintaining the temperature at $37^{\circ} \mathrm{C}$. Isometric contractions of tracheal rings were measured by the transducer (Force Transducers) coupled to the amplifier (BridgeAmp) connected to PC running ChartV5 software, all from ADInstruments (Dunedin, New Zealand). An equilibration period of 90 minutes was allowed in Krebs PSS, at the end of the period, the tracheal rings were stimulated with histamine in order to establish viability. After equilibration, the tracheal rings were exposed to aminophylline as positive control drugs and medicinal plants extract of $C$. aeruginosa and C. mangga according to the experimental protocol. In each preparation, a single concentration-relaxation curve was obtained. The relaxant effect induced by positive control drug and medicinal plant extracts was expressed as the reverse percentage of initial contraction force, which was elicited by histamine in tracheal rings (Ozolua et al. 2010; Janbaz et al. 2011; Lima et al. 2011).

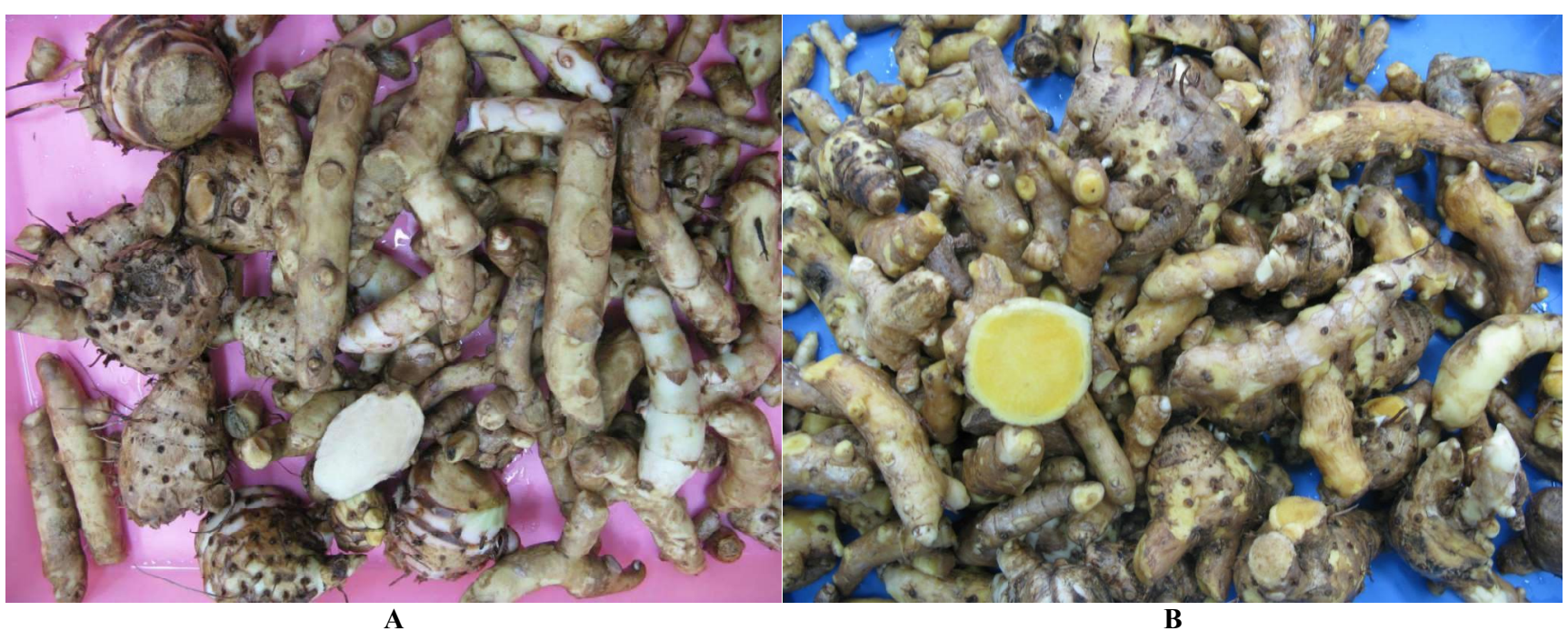

Figure 1. A. Rhizome of Curcuma aeruginosa Roxb., B. Rhizome of Curcuma mangga Val. Zijp 


\section{Anti-inflammatory activity}

Anti-inflammatory activity of medicinal plant extracts was measured by membrane stabilization and lipoxygenase inhibition test. For membrane stabilization test, blood samples were collected into an anticoagulant and centrifuged at $3000 \mathrm{rpm}$ for 10 minutes at room temperature. The supernatants (plasma and leucocytes) were carefully removed while the packed red blood cell was washed in fresh normal saline. The process of washing and centrifugation were repeated five times until supernatants were clear. The membrane stabilizing activity assay was carried out using erythrocyte suspension while Indomethacin was used as drug standard. The mixtures consisted of hyposaline sodium chloride, sodium phosphate buffer, erythrocyte suspension, drug standard, plant extracts and final reaction mixtures were mixed to produce isosaline. Drugs were mixed in the blood control, while the drug control did not contain the blood suspension. The reaction mixtures were incubated at $56^{\circ} \mathrm{C}$ for $30 \mathrm{~min}$ on a water bath. The tube was cooled under running water followed by centrifugation at $5000 \mathrm{rpm}$ for $10 \mathrm{~min}$ at room temperature. The supernatant was collected. The absorbance of the released hemoglobin from the supernatant was measured at $560 \mathrm{~nm}$ (Omale and Okafor 2008; Oyedapo et al. 2010).

For lipoxygenase inhibition test, a mixture of a solution of sodium borate buffer and lipoxygenase enzyme was incubated with plant extract sample at room temperature for 5 minutes. The reaction was started by the addition of linolic acid substrate. The absorbance of the resulting mixture was measured at $234 \mathrm{~nm}$ as a function of time at a rate of one measurement/minutes (3 readings). Indomethacin was used as a positive standard (Khasawneh et al. 2011; Singh et al. 2012).

\section{Data analysis}

Tracheheospasmolytic activity is tabulated in the mean $\pm \mathrm{SE}$ curve of the dose-response. The value of $\mathrm{EC}_{50}$ was calculated. The homogeneity and variance analysis was conducted when the data showed the normal distribution and variance followed by t-test analysis. The significant difference was performed when $\mathrm{p}<0.05$. Membrane stabilization activity and lipoxygenase inhibition were tabulated in mean $\pm \mathrm{SD}$ form, in order to calculate $\mathrm{EC}_{50}$ values. The difference between the control was performed based on t-test analysis with the significance of $p<0.05$.

\section{RESULTS AND DISCUSSION}

\section{Tracheospasmolytic activity}

The results of spasmolytic activity of ethanol extract of $C$. aeruginosa on separated organ of trachea guinea pig at $0.01,0.03,0.1,0.3,1$ and $3 \mathrm{mg} / \mathrm{ml}$ concentrations were as follows: $(4.90 \pm 2.40),(2.44 \pm 1.86),(1.02 \pm 3.08),(0.01 \pm$ $3.51),(-0.48 \pm 3.69),(-2.02 \pm 4.33) ;$ C. mangga $(3.39 \pm$ $2.77),(3.25 \pm 2.70),(3.13 \pm 2.57),(3.11 \pm 2.58),(2.98 \pm$ $2.47),(1.90 \pm 2.23)$; and on control (solvent extract) obtained results $(2.31 \pm 0.61),(3.68 \pm 0.42),(5.54 \pm 0.97)$,
$(6.00 \pm 0.47),(5.85 \pm 0.57),(4.80 \pm 0.86)$; whereas in aminophylline obtained results $(0.82 \pm 1.01),(0.68 \pm 1.32)$, $(-3.94 \pm 3.19),(-23.78 \pm 5.53),(-57.78 \pm 5.14),(-93.68 \pm$ $3.01)$. The result of trachea relaxation between negative control, aminophylline and group with plant extracts is presented in Figure 2. The result showed that the decrease of spasmolytic activity of $C$. aeruginosa and $C$. mangga in the guinea pig tracheal tone was significantly better ( $p$ $<0.05)$ than that in negative control.

The $\mathrm{EC}_{50}$ value of $C$. aeruginosa $(0.020 \pm 0.004)$ and $C$. mangga $(0.039 \pm 0.005)$ was higher than aminophylline $(0.016 \pm 0.005)$ as a positive control. This shows that the effect of the plant extract was not as strong as aminophylline, as shown in Figure 3. However, the $C$. aeruginosa had an indifferent value from that of aminophylline as a positive control. This suggests that $C$. aeruginosa has a better efficacy than $C$. mangga as spasmolytic when they were compared with aminophylline.

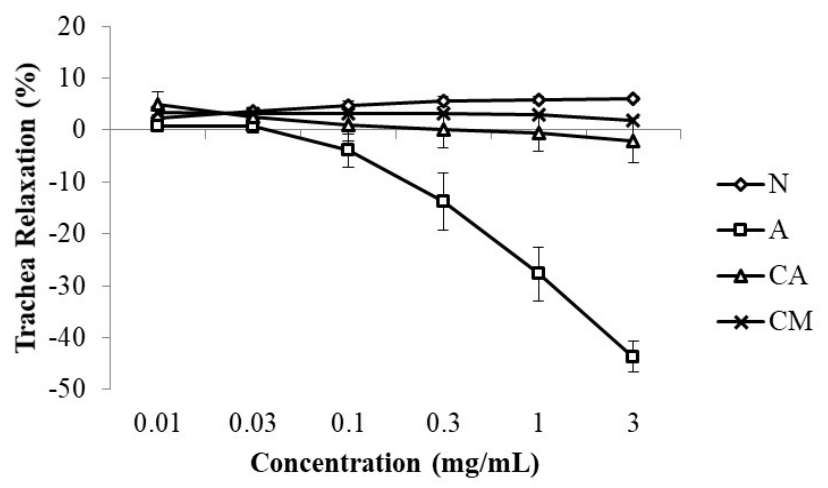

Figure 2. Graph of trachea relaxation differences between $C$. aeruginosa (CA), C. mangga (CM), aminophylline (A) as the positive control and negative control $(\mathrm{N})$ in trachea isolates organ of guinea pig

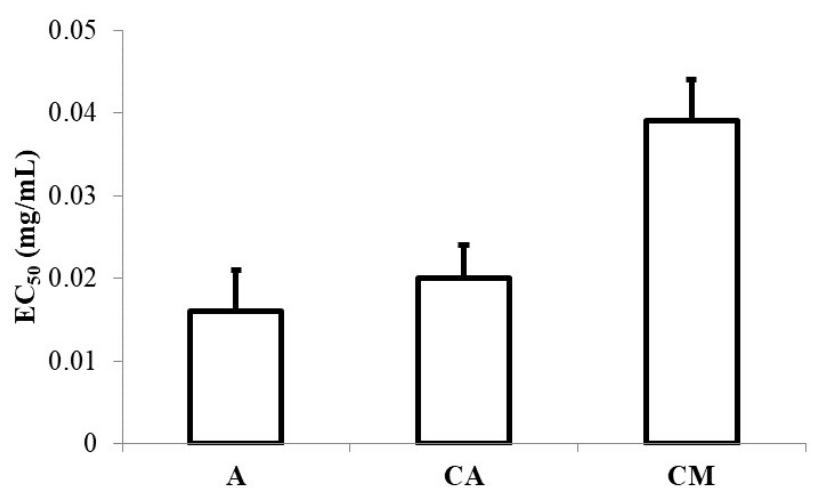

Figure 3. The $\mathrm{EC}_{50}$ result on tracheospasmolytic activity between C. aeruginosa (CA), C. mangga (CM) and aminophylline (A) as a positive control $(\mathrm{p}<0.05)$. 


\section{Anti-inflammatory activity}

The result of membrane stabilization test showed that the $\mathrm{EC}_{50}$ value of $C$. aeruginosa $(47.76 \pm 1.57) \mathrm{mg} / \mathrm{mL}$ and C. mangga $(67.50 \pm 0.97) \mathrm{mg} / \mathrm{mL}$ were higher compared with indomethacin $(26.39 \pm 2.91) \mathrm{mg} / \mathrm{mL}$ as the positive control, as shown in Figure 4. The results of lipoxygenase inhibition test showed that the $\mathrm{EC}_{50}$ value of $C$. aeruginosa $(-111.11 \pm 2.30) \mu \mathrm{g} / \mathrm{mL}$ and $C$. mangga $(-101.98 \pm 1.32)$ $\mu \mathrm{g} / \mathrm{mL}$ were also higher than indomethacin $(-282.84 \pm$ 7.41) $\mu \mathrm{g} / \mathrm{mL}$ as the positive control (Figure 5). The smaller $\mathrm{EC}_{50}$ concentration determines the better anti-inflammatory activity based on membrane stabilization test and lipoxygenase inhibition. The results showed that indomethacin as positive control had better antiinflammatory activity than that in $C$. aeruginosa and $C$. mangga, based on membrane stabilization test and lipoxygenase inhibition.

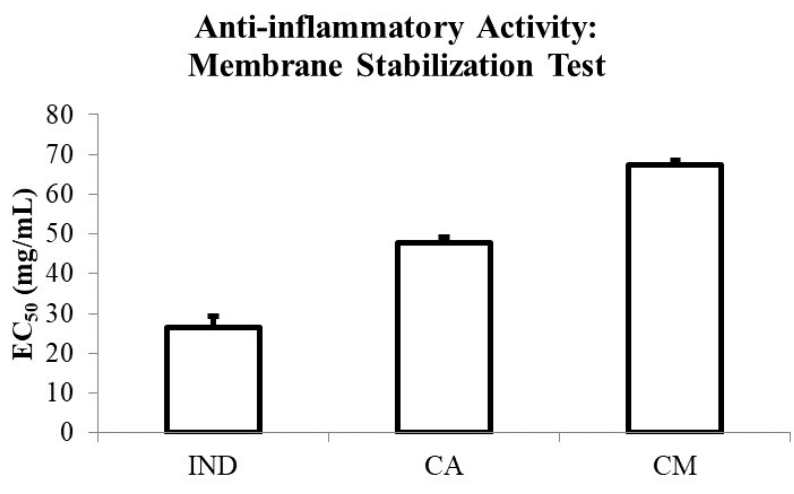

Figure 4. The $\mathrm{EC}_{50}$ results on membrane stability test between $C$. aeruginosa (CA) and C. mangga (CM) with indomethacin (IND) as the positive control $(\mathrm{p}<0.05)$

Anti-inflammatory Activity: Lipoxygenase Inhibition Test

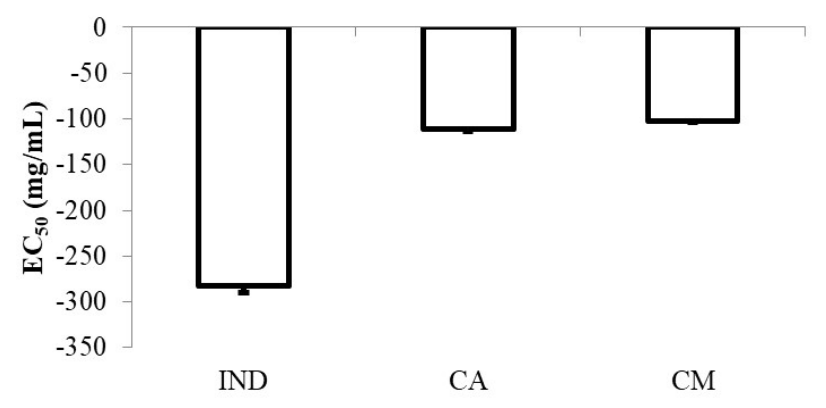

Figure 5. The $\mathrm{EC}_{50}$ results on lipoxygenase inhibition test between $C$. aeruginosa (CA) and C. mangga (CM) with indomethacin (IND) as the positive control $(p<0.05)$

\section{Discussion}

Curcuma longa from genus Curcuma is the most important medicinal plants, which is traditionally used as antiasthma for the treatment of respiratory disorders such as asthma, bronchitis and allergic reactions in the respiratory tract (Gonuguntla et al. 2013). Anti-asthmatic and antioxidant property of $C$. longa has been tested in the experimental animal model of asthma (Prasad et al. 2009). Bronchodilatory effect of $C$. longa may be due to the mast cell stabilizing activity, suppression of immunoglobulin E, and inhibition of inflammatory mediators (Gohil and Mehta 2011; Dongre et al. 2015).

Curcuma caesia, C. zedoaria, C. aeruginosa, and $C$. mangga are another Curcuma species traditionally used as asthma treatment. C. caesia tested antiasthma for its relaxant effect in guinea pig trachea has been successfully reported as powerful protection against histamine-induced bronchospasm (Paliwal et al. 2011). C. zedoaria significantly decreased milk induced leukocytosis and showed anti-inflammatory activities (Pathan et al. 2016b). In this study, the examination of antiasthma effects of $C$. aeruginosa and $C$. mangga has been firstly reported.

Curcuma aeruginosa is known in Indonesia as "temu ireng" and "pink and blue ginger" in English (Nurcholis et al. 2012; Simoh and Zainal 2015). C. aeruginosa has been used as traditional medicine in South and Southeast Asia for gastrointestinal and uterine disorders or parasitic and fungal infection (Jose and Thomas 2014; Hossain et al. 2015; Theanphong et al. 2015). Sesquiterpenes have been found as common chemical constituents of C. aeruginosa (Suphrom et al. 2012).

Curcuma mangga was known as "temu mangga" in Indonesia, meaning mango-like turmeric (Kaewkroek et al. 2010). The rhizomes of $C$. mangga are used as traditional treatment for stomach and chest pain, fever, debility, bronchitis, aphrodisiac, postpartum care and cancer-related diseases (Wan-Ibrahim et al. 2010; Malek et al. 2011). The composition of $C$. mangga is dominated by sesquiterpenes and monoterpenes (Kamazeri et al. 2012).

It is suggested that curcumin with other chemical compounds from $C$. aeruginosa and $C$. mangga could show antiasthma activity. Anti-asthmatic and antioxidant property of curcumin has been tested in the experimental animal model of asthma (Houssen et al. 2010). Curcumin is acted to inhibit histamine release (Kale et al. 2012). Curcumin alleviates the pathological changes of chronic asthma, by reducing lung and airway inflammation in asthma induced animal (Chong et al. 2014; Yang et al. 2017). Curcumin improves the airway obstruction by inhibiting mast cell degranulation so that it is safely used as therapy for asthma patients (Subhashini et al. 2013; Abidi et al. 2014; Chauhan et al. 2014).

The results of this study indicate that ethanol extract of C. aeruginosa and C. mangga has an antiasthma effect based on the tracheospasmolytic and anti-inflammatory activity. Therefore, C. aeruginosa and C. mangga can be developed as a source of the new antiasthma drug. 


\section{ACKNOWLEDGMENTS}

Acknowledgments to the Directorate General for Research and Development, Ministry of Research and Technology Higher Education of the Republic of Indonesia, for financing this research, as part of the implementation of Basic Research of Flagship University Year of 2018.

\section{REFERENCES}

Abidi A, Gupta S, Agarwal M, Bhalla HL, Saluja M. 2014. Evaluation of efficacy of curcumin as an add-on therapy in patients with bronchial asthma. J Clin Diagn Res 8: HC19-HC24.

Akarchariya N, Sirilun S, Julsrigival J, Chansakaowa S. 2017. Chemical profiling and antimicrobial activity of essential oil from Curcuma aeruginosa Roxb., Curcuma glans K. Larsen \& J. Mood and Curcuma cf. xanthorrhiza Roxb. collected in Thailand. Asian Pac J Trop Biomed 7: 881-885.

Amit K, Vandana V. 2013. Medicinal properties of Acorus calamus. J Drug Deliv Ther 3: 143-144.

Chauhan PS, Subhashini S, Dash D, Singh R. 2014. Intranasal curcumin attenuates airway remodeling in murine model of chronic asthma. Intl Immunopharmacol 21: 63-75.

Chong L, Zhang W, Nie Y, Yu G, Liu L, Lin L, Wen S, Zhu L, Li C. 2014. Protective effect of curcumin on acute airway inflammation of allergic asthma in mice through Notch1-GATA3 signaling pathway. Inflammation 37: 1476-1485.

Dewangan MK, Dwivedi C, Sivna PL, Rao SP, Yadav R, Chandrakar K, Singh SS, Sinha D. 2014. Medicinal value of Curcuma cassia Roxb: An overview. Crit Rev Pharm Sci 3: 1-9.

Dongre PR, Bhujbal SS, Kumar D. 2015. Bronchodilatory activity of Curcuma longa, Zingiber officinale and Alpinia galanga based herbal formulation (AHF). Orient Pharm Exp Med 15: 341-346.

Gohil PV, Mehta AA. 2011. Evaluation of mast cell stabilizing and antianaphylactic activity of polyherbal formulation. Adv Biol Res 5: 304 308.

Gonuguntla HK, Rao P, Naik B. 2013. Asthma diagnosis and treatment 1011. OZAC- a herbal medicine for bronchial asthma. World Allergy Organ J 6 (Suppl 1): P11. DOI: 10.1186/1939-4551-6-S1-P11.

Hossain CF, Al-Amin M, Sayem ASM, Siragee IH, Tunan AM, Hassan F, Kabir MM, Sultana GNN. 2015. Antinociceptive principle from Curcuma aeruginosa. BMC Compl Altern Med 15: 191. DOI: 10.1186/s12906-015-0720-6.

Houssen ME, Ragab A, Mesbah A, El-Samanoudy AZ, Othman G, Moustafa AF, Badria FA. 2010. Natural anti-inflammatory products and leukotriene inhibitors as complementary therapy for bronchial asthma. Clin Biochem 43: 887-890.

Janbaz KH, Hamid I, Mahmood MH, Gilani AH. 2011. Bronchodilator, cardiotonic and spasmolytic activities of the stem barks of Terminalia arjuna. Can J Appl Sci 1: 104-120.

Jose S, Thomas TD. 2014. Comparative phytochemical and antibacterial studies of two indigenous medicinal plants Curcuma caesia Roxb. and Curcuma aeruginosa Roxb. Intl J Green Pharm 8: 65-71.

Kaewkroek K, Wattanapiromsakul C, Tewtrakul S. 2010. Antiinflammatory mechanisms of compounds from Curcuma mangga rhizomes using RAW264.7 macrophage cells. Nat Prod Comm 5: 1547-1550.

Kale RN, Patil RN, Patil RY. 2010. Asthma and herbal drugs. Intl J Pharm Sci Res 1: 37-42.

Kamazeri TSAT, Samah OA, Taher M, Susanti D, Qaralleh H. 2012. Antimicrobial activity and essential oils of Curcuma aeruginosa, Curcuma mangga, and Zingiber cassumunar from Malaysia. Asian Pac J Trop Med 5 (3): 202-209. DOI: 10.1016/S1995-7645(12)60025$\mathrm{X}$.

Karaman M, Firinci F, Cilaker S, Uysal P, Tugyan K, Yilmaz O, Uzuner N, Karaman O. 2012. Anti-inflammatory effects of curcumin in a murine model of chronic asthma. Allergol Immunopathol (Madr) 40: 210-214.
Kasper DL, Hauser SL, Jameson JL, Fauci AS, Longo DL, Loscalzo J. 2015. Harrison's principles of internal medicine. 19th ed. McGraw Hill Education. New York.

Khasawneh MA, Elwy HM, Hamza AA, Fawzi NM, Hassan AH. 2011. Antioxidant, anti-lipoxygenase and cytotoxic activity of Leptadenia pyrotechnica (Forssk.) Decne polyphenolic constituents. Molecules 16: 7510-7521.

Lima JT, Almeida JRG, Mota KSL, Lucio ASSC, Camara CA, Filho JMB, Silva BA. 2011. Selective spasmolytic effect of a new furanoflavoquinone derivative from diplotropin on guinea-pig trachea. J Chem Pharm Res 3: 249-258.

Malek SNA, Lee GS, Hong SL, Yaacob H, Wahab NA, Weber JFF, Shah SAA. 2011. Phytochemical and cytotoxic investigations of Curcuma mangga rhizomes. Molecules 16: 4539-4548.

MoH RI (Ministry of Health Republic of Indonesia). 2008. Farmakope Herbal Indonesia. 1st ed. Ministry of the Health Republic of Indonesia. Jakarta.

Nurcholis W, Priosoeryanto BP, Purwakusumah ED, Katayama T, Suzuki T. 2012. Antioxidant, cytotoxic activities and total phenolic content of four Indonesian Medicinal Plants. Valensi 2: 501-510.

Omale J, Okafor PN. 2008. Comparative antioxidant capacity, membrane stabilization, polyphenol composition and cytotoxicity of the leaf and stem of Cissus multistriata. Afr J Biotechnol 7: 3129-3133.

Oyedapo OO, Akinpelu BA, Akinwunmi KF, Adeyinka MO, Sipeolu FO. 2010. Red blood cell membrane stabilizing potentials of extracts of Lantana camara and its fractions. Intl J Plant Physiol Biochem 2: 4651.

Ozolua RI, Eboka CJ, Duru CN, Uwaya DO. 2010. Effects of aqueous leaf extract of Bryophyllum pinnatum on guinea pig tracheal ring contractility. Nigerian J Physiol Sci 25: 149-157.

Pakkirisamy M, Kalakandan SK, Ravichandran K. 2017. Phytochemical screening, GC-MS, FT-IR analysis of methanolic extract of Curcuma caesia Roxb (Black Turmeric). Pharmacog J 9: 952-956.

Paliwal P, Pancholi SS, Patel RK. 2011. Comparative evaluation of some plant extracts on bronchoconstriction in experimental animals. Asian J Pharm Life Sci 1: 52-57.

Papadakis MA, McPhee SJ. 2013. Current Medical Diagnosis and Treatment. 52nd ed. McGraw Hill Lange, New York.

Paramita S, Kosala K, Dzulkifli D, Saputri DI, Wijayanti E. 2017. Antiinflammatory activities of ethnomedicinal plants from Dayak Abai in North Kalimantan, Indonesia. Biodiversitas 18: 1556-1561.

Pathan A, Alshahrani A, Al-Marshad F. 2015. Pharmacological effect of Curcuma zedoaria rhizomes on milk induced eosinophilia in the management of Asthma. Intl $\mathrm{J}$ Ethnobiol Ethnomed 1 (1), http://creativecommons.org/licenses/

Pathan AR, Vadnere G, Sabu M. 2016a. Curcuma caesia rhizomes: evaluation of antiasthmatic effect by using clonidine induced mast cell degranulation. Neuropharm J 1: 7-12.

Pathan AR, Vadnere G, Sabu M. 2016b. Evaluation of antiasthmatic effect of Curcuma zedoaria rhizomes by using milk induced leukocytosis in mice. Neuropharm J 1: 13-17.

Prasad R, Lawania RD, Manvi M, Gupta R. 2009. Role of herbs in the management of asthma. Pharmacog Rev 3: 247-258.

Rahayu M, Sangat HM, Lestari VB. 2011. The ethnobotanical aspects of Curcuma spp. in Javanese Traditional Medicine. Proceedings of $2^{\text {nd }}$ International Symposium on Temulawak and $40^{\text {th }}$ Meeting of National Working Group on Indonesian Medicinal Plant. Biopharmaca Research Center, Institute of Research and Community Services, Bogor Agricultural University, Indonesia. Bogor, 24-29 May 2011.

Rajamma AG, Bai V, Nambisan B. 2012. Antioxidant and antibacterial activities of oleoresins isolated from nine Curcuma species. Phytopharmacol 2: 312-317.

Shakeri F, Soukhtanloo M, Boskabady MH. 2017. The effect of hydroethanolic extract of Curcuma longa rhizome and curcumin on total and differential WBC and serum oxidant, antioxidant biomarkers in rat model of asthma. Iran J Basic Med Sci 20: 155-165.

Simoh S, Zainal, A. 2015. Chemical profiling of Curcuma aeruginosa Roxb. rhizome using different techniques of solvent extraction. Asian Pac J Trop Biomed 5: 412-417.

Singh B, Nadkarni JR, Vishwakarma RA, Bharate SB, Nivsarkar M, Anandjiwala S. 2012. The hydroalcoholic extract of Cassia alata (Linn.) leaves and its major compound rhein exhibits antiallergic activity via mast cell stabilization and lipoxygenase inhibition. J Ethnopharmacol 141: 469-473. 
Subhashini S, Chauhan PS, Kumari S, Kumar JP, Chawla R, Dash D, Singh M, Singh R. 2013. Intranasal curcumin and its evaluation in murine model of asthma. Intl Immunopharmacol 17: 733-743.

Suphrom N, Pumthong G, Khorana N, Waranuch N, Limpeanchob N, Ingkaninan K. 2012. Anti-androgenic effect of sesquiterpenes isolated from the rhizomes of Curcuma aeruginosa Roxb. Fitoterapia 83: 864871.

Theanphong O, Mingvanish W, Kirdmanee C. 2015. Chemical constituents and biological activities of essential oil from Curcuma aeruginosa Roxb. rhizome. Bull Health Sci Technol 13: 6-16.
Wan-Ibrahim WI, Sidik K, Kuppusamy UR. 2010. A high antioxidant level in edible plants is associated with genotoxic properties. Food Chemist 122: 1139-1144.

WHO. 2018. Factsheets: Asthma. World Health Organization, Geneva, Switzerland. www.who.int/mediacentre/factsheets/fs307/en/.

Yang X, Lv JN, Li H, Jiao B, Zhang QH, Zhang Y, Zhang J, Liu YQ, Zhang M, Shan H, Zhang JZ. 2017. Curcumin reduces lung inflammation via $\mathrm{Wnt} / \beta$-catenin signaling in mouse model of asthma. J Asthma 54: 335-340. 